\title{
Assessment of Induction to Teaching Program: Opinions of Novice Teachers, Mentors, School Administratorsi
}

\author{
Bilge Çam Aktaş \\ Faculty of Education, Anadolu University, Turkey
}

Copyright $\odot 2018$ by authors, all rights reserved. Authors agree that this article remains permanently open access under the terms of the Creative Commons Attribution License 4.0 International License

\begin{abstract}
This research aimed at evaluating Induction to teaching Program according to the opinions of novice teachers, mentors and administrators is a qualitative research carried out in the pattern of phenomenology. The data of the study were collected through semi-structured interviews with 40 novice teachers, 43 mentors and 5 school administrators. Content analysis was done in the analysis of the data. As a result of the research, it was concluded that an information meeting was held at the beginning of the training program but it was inadequate, that the mentors were not volunteers, that they were more planned and programmed compared to the teaching practice received during the undergraduate education, that it was taken more serious, that performing the induction to teaching program at the place appointed had advantages, and that there are several issues caused by the novice teacher, mentor and the process. For the continuity of the application, proposals such as reducing the number of forms filled in the process, ensuring volunteerism in mentors, supervision of the interaction between the novice teacher and mentor, performing the processes at the place to which they are appointed were developed.
\end{abstract}

Keywords Mentoring, Novice Teacher, Mentor Teacher, Illuminative Program Evaluation Model

\section{Introduction}

According to the Basic Law of National Education No. 1739 in Turkey, "Teaching is a specialization profession taking on the government's education, teaching and related administrative duties". Thus, the education and training of teachers is very important. Pre-service training, start-up training and in-service training could be mentioned in the training of teachers. Pre-service training is the name given to the work carried out and the training received before starting the occupation. Start-up training includes the training to adapt to the profession for the first few years. In-service training is organized to provide continuity in professional development at all stages of the occupation. As in all professions, teachers seem to face many problems, especially in the first years, such as classroom management, motivating students, individual problems of students, incompatibility between theory and practice, cooperating with parents, and adapting to the profession and the school. $[1,2,3]$ Hence, start-up training is especially important. It may be argued that a one-to-one mentoring approach [4] based on the sharing of professional knowledge and experience of a person with a younger and inexperienced colleague is mainly used in Turkey. In this context, firstly, after the conceptual framework of mentoring is explained, the teachers will be given an explanation about the training to get started.

Mentoring is a process that can be described as developmental for both sides, where an individual who is experienced in a professional field transfers his knowledge, skills and experiences to the inexperienced individual who has just started. [5,6,7] According to Daresh [8], mentoring is a continuing process in which employees are guided and supported by each other so that the aims of a professional institution can be better understood and fulfilled by their employees. Packard [9] describes mentoring as a synoptic and long-term relationship with the individual who supports the professional, academic and personal development of the individual. According to Shea [10], mentoring is the sharing of knowledge and experience between individuals without regard to status. When the definitions of mentoring are examined, it is a process in which an experienced person who is being consulted and an inexperienced individual who has just started working support their professional, academic and personal development in a determined process. However, in this process it is observed that flow of sharing the experience is mostly from the experienced individual to the inexperienced individual.

Yarrow and Millwater [11], argue that effective mentoring is a strong source of professional learning. Mentoring practice reduces the feelings of loneliness of novice teachers, supports their self-confidence development, supports the development of new skills, 
strengthens their risk taking behaviors and improves areas such as problem solving, self-assessment and professional development [12, 13]. Baker and Pitts [14] argue that mentoring promotes emotional support and friendship relationships and supports the dimension of occupational help for work. From an organizational perspective, it is regarded to contribute to the improvement of intra-organizational communication, the establishment of confidence and moral relation among the employees and the increase of the efficiency levels of the employees [15]. When assessed from the point of view of mentor, benefits such as providing job satisfaction, developing personal skills, and increasing the level of academic motivation through those who seek mentoring are mentioned $[16,17]$.

Awaya et al. [18] argue that the relation between the mentor and the prospective teacher should be perceived as a process, and that the relationship in this process should be equal. They describe the mentor as a guide giving information, and a motivation source. It is pointed out that there is a need for mentors to be role models, to follow the teaching process and give feedback, and to develop mentoring skills in addition to teaching, to have a relationship based on mutual respect, trust and professionalism in a successful mentor, mentee relationship [19]. In the mentoring process, mentors should be open to sharing their knowledge, skills and experiences, be psychologically supportive and motivated, be an inspiration source, evaluate the performance of the novice teacher, provide feedback, be easily accessible and play a leading role [20,21]. Daresh [8] states that a good mentor must be experienced, have good classroom management skills, be open to learning and self-assessment, have problem solving, listening and observation skills. He talked about their responsibilities such as recommending, communicating, counseling, guiding, modeling and protecting the novice teachers.

It is possible to say that mentoring has a significant place in pre-service and in service in teacher training in Turkey. Students receive mentoring from practice teachers in practice schools and practice instructors in faculties in the teaching practice courses they take in educational faculties during the pre-service period. In the first year, they are appointed as mentors; mentoring services are offered through a mentor teacher assigned to them in novice teacher training.

Until 2016, induction to teaching programs in Turkey were executed in three phases, which are primary training (50 hours), preparatory training (110 hours) and applied training (220 hours), as it was specified in the communiques bulletin numbered 2423 and dated 30.01.1995. Primary training involved the training about common traits and qualities of public officers; preparatory training involved the training about classes and duties of service to which novice teachers are assigned; and applied training involved the internship that was exercised by novice teachers relating to their classes and duties of service [22] In accordance with the regulations, novice teachers may not independently assume watch duty, attend classes while escorted by the school counselor, and may not give lessons on their own [22]. However, during the application period of that regulation, it was a known fact that novice teachers were attending classes on their own. Due to the various problems in the process and the inability to obtain sufficient efficiency, the start-up trainings were renewed by the Ministry of National Education Teacher Appointment and Relocation Regulation published in the Official Gazette dated April 17, 2015 and numbered 29329. According to this regulation, it is deemed appropriate for the novice teachers to undergo an upbringing process in the first period they are appointed [23]. Prospective teachers appointed to the teaching profession at the second term of February 2016 had been appointed to the province order, where they would take their training by making a second preference, As a result of the work carried out in the Provincial Directorates of National Education, they started to work in the first week of March 2016 with the mentors in the schools where they will complete their induction training.

According to this new practice, novice teachers undergo a training period in the first six months of their candidacy. In accordance with the training program determined by the Ministry, the training process takes place in educational institutions, under the responsibility of the administrator and mentors of the relevant institution. Within the scope of this program, novice teachers are required to perform some in-class, in-school and out-of-school activities and attend in-service activities. Independent lesson and watch duties are not assigned to the novice teacher in this process. They attend classes together with the mentors, and observe the mentors on watch duty [24]. This practice is similar to the mentoring practices in many countries. Job training is practiced in Australia, France, Greece, Israel, Italy, Japan, South Korea, Switzerland, New Zealand and some states of the United States [25].

The mentor is the person who guides the novice teachers who have just started to work. School administrators were appointed in the selection of the mentors who will guide the novice teachers with the aforementioned regulation. It is envisaged that the teachers to be selected should have at least 10 years of service time, take part in national or international projects, participate in social and cultural activities, be strong in communication skills and representation, be a pioneer in the profession and be in the same area as the novice teacher [24].

It is seen that the works conducted regarding the novice teachers is limited in the literature due to the fact that the start-up trainings are new in Turkey. It can be said that these studies are more focused on the opinions $[26,27,25,28,29,30,31,32]$ of the novice teachers on their start-up training. In the studies in the literature, it was seen that the novice teachers were satisfied with their start up training they received and they reflected their opinions on 
the continuity of the program with some improvements. Increasing numbers of studies on the subject is important in terms of improving the quality of mentoring-based start-up training which is new to Turkey. Based on this requirement, it was aimed to evaluate the induction to teaching program applied in this research in line with the opinions of all the people participating in the process (novice teachers, mentors, school administrators). In line with this objective, answers will be sought to the following questions:

What are the opinions of the novice teachers, advisors and school administrators:

1. On the process of induction to teaching program?

2. What are their views on the problems experienced within induction to teaching program?

3. What are the recommendations for the continuity of the application?

\section{Method}

\section{Research Design}

In this research, a phenomenological design, from the qualitative research methods, is used which reveals the individual perceptions, views and common practices of a particular phenomenon, which deals with real experiences, and which describes, explains and interprets the meanings formed by the participants $[33,34,35,36]$. In line with this, to evaluate the induction to teaching program applied in the Turkish context, this research study aimed to reveal the experiences of all the people participating in the process (novice teachers, mentors, school administrators). Accordingly, the phenomenon determined within the scope of the research is the phenomenon of "induction to teaching". Towards the aim of understanding this phenomenon, the comprehension and the evaluation of experiences of the novice teachers who underwent the training and the mentor teachers responsible for providing the training and the school administrators was possible through the study of the meanings they produced out of the experience.

There are a couple of reasons why this study was designed as a phenomenology. Phenomenological studies may be applied to single cases like the current one, in order to illuminate the effects of a situation in different contexts or individuals with differing perspectives. Secondly, the aim of the study was to reveal the lived experiences of those who were part of the induction to teaching program in maximum depth. To reach the maximum depth targeted, data was collected in three different schools with differing levels with the maximum number of novice teachers, mentor teachers and administrators possible. This also makes it possible for this study to avoid theoretical prejudices and distortions that stem from our presuppositions or taken-for-granted assumptions through reduction of data from varying sources in varying contexts.
Phenomenology is a tool to enlighten the subjective construction of reality, which is why this study was designed as a phenomenological study. The philosophical ground in phenomenology leads to the assumption that the reality of workplace is defined by the subjectivity of organizational members [78]. In our context, workplace being the schools and organizational members of the induction program being novice and mentor teachers and school administrators, their subjective construction of reality concerning the induction program was best to be analysed through a phenomenological point of view. Finally, the program evaluation model that was intended to be used for this study, the Illuminative program evaluation model, is thought to be better implemented through a phenomenological approach as it aims to reflect and combine the perspectives, views and experiences of all participants of the program.

As a program evaluation approach in the research, the Illuminative program evaluation model was used from participant-oriented program evaluation approaches [37]. Participant-oriented program evaluation approaches are inductive in that they incorporate data from different sources, combine the views of all participants, and reflect the full realities of the program in detail [37]. The illuminative evaluation model also aims to reveal the special cases, the problems encountered and the dimensions and issues that are significant to the participants in the program with the views of the participants [38]. In this respect, it is descriptive and process oriented. In the illuminative evaluation model, the evaluation process is carried out in three stages, namely observation, inquiry and explanation [39]. During the observation stage, information about the program is collected. In this research, for this stage, "Prospective Teacher Training Program" prepared by the Ministry of National Education General Directorate of Teacher Training and Development [24] was examined and also the training materials presented for the mentor teachers were examined in detail. In the second stage, which is the inquiry stage, a systematic and selective investigation is conducted. In this research, for the inquiry stage, interview questions were prepared for novice teachers, mentor teachers, and school administrators through the main components of the program during the observation stage and interviews were held. In the final stage, which is explanation, the findings obtained are discussed within the context of cause and effect. Within the scope of this research, data collected from all participants and from different contexts were analyzed comparatively and the results were discussed.

\section{Study Group}

In the phenomenological research and the illuminative evaluation model, the focus of the research of the data source is the individuals or groups who experienced and 
can reflect their experience $[35,37]$. Hence, the study group of the study consisted of 40 novice teachers who are currently in the induction to teaching program, 43 mentor teachers who are metoring to these novice teachers and who are also the teachers of the program, 5 school administrators who acted as administrators in the schools where the novice and mentor teachers are working and who are the advisors of the program. In order to ensure contextual diversity in the formation of the study group, teachers in different branches who are working in primary, secondary and high school education were found for the program.10 novice teachers, 10 mentor teachers and one school administrator from elementary schools; 17 novice teachers, 17 mentor teachers and 3 school administrators from middle schools; and 13 novice teachers, 16 mentor teachers and one school administrator from high schools were interviewed with. Branches of the novice teachers and the mentor teachers consist of 18 branches such as class, technology design, music, English, special education, social studies, science, religious culture and moral knowledge, counseling, information technologies, Turkish, geography, Turkish philology, electrics, electronics, industrial automation, furnishing, interior design, and mathematics. Lengths of service of the mentor teachers vary between 11 to 38 years. Only 16 of the novice teachers have already had a teaching experience. Two of the school administrators works as school principals, and three of them as vice principals.

\section{Data Collection Tools}

Data were collected through semi-structured interviews within the scope of the research. To this end, the researchers used interview forms prepared exclusively for novice teachers, mentor teachers and school administrators.

While preparing semi-structured interview forms, relevant sections of the "Induction to Teaching Program" (MEB, 2016b) prepared by the National Ministry of Education's Directorate General for Teacher Training and Improvement and the National Ministry of Education's No. 29329 Teacher Assignment and Transfer Regulations [23] published on the official gazette on the date of 17 April 2015 were examined, and questions in the interview forms were developed as a result of these examinations. The form developed was initially presented to three experts in the field, revised in the light of their feedback, and then pilot interviews were conducted with a novice teacher, a mentor teacher, and a school administrator. During the pilot interviews, questions that came out to be unclear were identified and interview forms were finalized as a result of the feedback from interviewees about how to ask these questions.

Required official consent was received from the relevant National Education Directorate in the collection of data. Receiving consent from and signing contracts with participants are required for video/audio recording and the collection of research data in qualitative studies. To this aim, contracts were signed with the participants.

\section{Collection of the Data}

Data were collected by audio-recorded semi-structured interviews via forms developed by the researcher. Participants' consent was obtained prior to each interview regarding the sound recording. The interviews took place on school libraries, science laboratories and assembly halls depending on the physical conditions of the school. Interviews lasted for 15 - 35 minutes.

\section{Analysis of the Data}

Initially, audio recordings were transferred to written media in the analysis of the data. Accuracy of the transferred data was checked by an expert. Content analysis was done in the analysis of the data. The data were individually examined by the researcher with the help of Nvivo 9 packaged software, properly coded and themed, and then presented to another field expert for independent coding and theming for reliability analysis. As a result of the reliability analysis, a consensus was reached at the level of .81, and it was concluded that the data were reliably analyzed [40].

\section{Findings}

As a result of the analysis made, findings are presented under six main themes. These main themes will be presented respectively as; Introduction to the Process, Comparison with Teaching Practice, Comparison with the previous Induction to Teaching Program, Place of Training, Issues and Suggestions. Sub-themes reached under these main themes are discussed under these headings.

\section{Introduction to the Process}

Under this main theme, subthemes are listed as: Information on novice teacher process, the initial meeting of mentor and novice teachers, student reactions, being a novice teacher and choosing a mentor.

Novice teachers and mentor teachers stated that an informative meeting was held before the process started but that the information given at this meeting was inadequate. Direct quotations from the views of the novice teachers and mentor teachers are as follows: NT7 - "Yes, an informative meeting was held before the start of the novice teacher training process in Eskişehir. We were informed and learned about the process. Then we started our duty as of March 1st. It was partly enough though there are certain question marks. I would say a little inadequate too. As the process continued, the level of qualification increased."NT14 - "A meeting was held at 
Süleyman Çakır Kız Anadolu Lisesi. We were informed there about how it would be. However, it was not enough. We have learned here what should be in the file content. It was mentioned how sacred being a teacher is. M9 said "We attended a 2-day seminar first. I do not think it was very useful. We then set up a group to avoid any problems that may arise. We informed each other. We lived, we learned. They explained some stuff at first. Of course, they informed us about things, however the seminar was too crowded. As I said we lived, we learned"

Almost all the novice teachers stated that they met with their mentors with the help of the school administrations. As of the students' reactions, they stated that the students were not behaving accepting but after a short time, they changed their behavior. Direct quotations from novice teachers in this regard are as follows: NT20 - "So at first you get a little nervous about this. Obviously, I did not get too much reaction from the students. I do not know, maybe I was so nervous and therefore, struggled as I once worked as a paid teacher in previous years. The students are not usually accepting. It is a bit hard to teach at that period because of the noise, but I did not face such challenges.NT32 - "At first they were a little shocked. As I was a stranger, they were silent in the first class. They observed. Then they continued the class normally, because they got used to it. My mentor informed me at the beginning. Thus I did not have many problems."

As to the process of becoming a mentor teacher, mentors stated that they did not volunteer as being mentors, and that these appointments were performed without informing them. M2 said "I did not volunteer to become a mentor. In fact, a message was sent to my phone by the Directorate of National Education. You have been appointed as a mentor. You have to attend the following seminar etc. Therefore, we attended it. We thought we have to respect the decision of our superiors. We were forced to do this"

The school administrators stated that they were informed about the process, that there were some criteria that were considered in the selection of the mentor, and that they had meetings with both the mentor and the novice teachers at the beginning of the process. SA2 "The province sent us a letter regarding mentoring. They must be working for at least 10 years, hardworking, successful and great at teaching. We picked 100 potential teachers and sent them to the provincial directorate for national education. We chose the ones that qualify." In this statement, the criteria of choosing a mentor is mentioned.

\section{Comparison with Teaching Practice}

When the new teaching practice was compared to the teaching practice the students receive during the undergraduate years, according to the novice teachers' opinions, it was found that the novice teacher process is much more comprehensive, that it was taken more seriously, that internship schools did not reflect the real school environment, that the undergraduate training was not practice-oriented and that the teaching practice was very structured.NT17 mentioned the fact that the novice teacher process is more comprehensive as follows: "These two are totally different, since we are appointed as teachers and have personal rights. Actually, they are two different processes, but they both need to be reviewed in different aspects. The skills we acquire there are different from the skills we acquire here. We were going there for an hour a week, sorry for once a week in our final year. However, here we work five days a week at the institution we have been fully appointed to. So, I can say that it is different in a way."

From the mentor teachers' views, the following sub-themes emerge: Intensive and long-lasting induction to teaching program, the training is as a teacher, the training is a more serious application, the teaching practice is just a course to be passed, there are deficiencies in counselors' behaviors in the teaching practice process, they do not get the chance to observe in the teaching practice process, university education is too theoretic. In general, it can be said that the teaching practice is weaker than the novice teacher teaching practice. M43 "I cannot leave the children to the interns and take a long break. The Interns said. We practiced but no one gave us feedback. In addition, we learned nothing. If such a thing is true, then there is no point of having this internship. There are those who see the interns as an advantage and there are those who really helps them ethically." It is pointed out here that there are some deficiencies in the behaviors of the guidance teachers in teaching practice.

According to the school administrators' views, the following sub-themes emerged: Novice teacher process is a practice that is taken more seriously, the teaching practice is just a course to be passed, the teaching practice is not performed with the teacher identity, the duration of teaching practice is short, administrative tasks are not learned, novice teacher process is much more comprehensive, novice teacher process is a practice that is taken more seriously. In general, it would not be wrong to say that the school administrators reported that the novice teacher process is a more serious, long-lasting and superior application.

\section{Comparison with the Previous Induction to Teaching Program}

When novice teachers were asked to compare their teaching process with the previous novice teaching process, some indicated that this system was better, while others stated that they think the former system was better. Some did not give their opinion because they have no knowledge of the previous system. NT13 "From a functional perspective, we received a type of training. We have to be ready. We received this training but the other friends was 
not able to receive it. We were one step ahead of them, however, I believe that after a month or so, we will be equal. Even if we received it 6 months ago, I believe that they will catch up in 1 month. I think teaching practice in the practice field is much more likely to renew itself and develop professionally in its own way." said a novice teacher, indicating that the previous induction to teaching program was much better.

When mentors were asked to compare their teaching process with the previous novice teaching process, some indicated that this system is better, while others stated that they think the former system is better. M15 "If the teacher is open to learning, you can be successful without even performing these steps. Because the guidance counselor would be appointed. This application may be a waste of time, maybe. This does not let them have the class to themselves. The other classes were theirs earlier. It was more real then." This statement indicated that the previous Induction to teaching Program was better.

When school administrators asked to compare the teaching practice process with the previous teaching process, it was seen that some school administrators think this system is better and that the other system is inadequate.

\section{Place of Training}

We can say that some novice teachers prefer to be in the place to which they are appointed and some prefer to be in the place they chose to be. NT11 who had spent his training where he was appointed to say: "It does not sound logical to me to feel ready for something psychologically. It would be better to go to a place to which we are appointed. I feel better like this. I will feel a little more prepared for the job. Most of our friends will start teaching right away and in my opinion, this might be a challenge for them. I have a lot of free time. I would have housework or other things to do. It helped me to have some spare time." NT27, who thinks being at the place he chose was a better idea said: "When I go there, I will work there for 6 months, then maybe the students I serve will pass to a higher grade and I will give them classes. Students are always aware of these things. We educate high school students. They might say "You used to come in the class with a mentor and now you are here with us alone", this might create a lower self-esteem."

Some mentor teachers prefer novice teachers to be in the place where they are appointed to and some prefer to be in the place they chose to be at. M26 "It would be better for them to be able to observe the environment, students and the social structure at the school they are appointed to" This statement indicates that it is better for them to be at the place to which they are appointed.

We can say that some school administrators prefer them to be in the place where they are appointed to and some prefer to be in the place they chose to be at. SA3 said "Yes, there is a problem there indeed. $80 \%$ of the people coming here will serve at east and southeast regions. Here, they are working in a school that pretty much has everything from projection tools to $4-5$ janitors. They can print as much as they want, they do whatever they like. However, who knows maybe when they go there, they will wake up at 06:30 and first light the stove. Maybe there will not be any principals, officers, janitors, and teachers. They also have the chance to start at a village school in Eskişehir hopefully." This statement indicates the fact that the practice should be carried out at the place appointed.

\section{Issues}

In the context of these issues, it was determined that there are issues caused by the mentors, novice teachers and the system.

In the issues caused by the mentor, the novice teachers gave opinions on the following matters: mentor and novice teacher compatibility, not getting feedback, insufficiency of the mentors, novice teacher comparison, and seeing bad examples. Mentor teachers stated their opinions on the following matters: The mentor's having more power, Mentorship's becoming the priority. NT33 "My teacher is not interested in anything. Everything is handed over to the other teacher. Since I did not know anything, I prepared uncompleted reports. Then I was told off by the other mentor. Then my mentor found out something. You should not boost anyone. He pointed at me while explaining what happens when you give them a boost. I still see the negative energy on their eyes." These words indicated how he had problems with his mentor. NT28 "We were faced with the following things when planning. The daily planning is done like this, have you ever seen it. Normally we have to see what is missing in the plan. However, they also got things from us or examined our daily plan. For example, socrate method is written as Socrates method. They act as if they hear it for the first time. I would expect them to give additional recommendations on what method to use." This statement indicates the insufficiency of the mentors.

In the issues caused by the novice teacher, various opinions were shared by the novice teachers under the themes of confusion of student and teacher identity, inability of feeling of belonging, anxiety and fear, being a burden to the mentor and coping with unwanted behaviors. NT34 "The students may call you "bro" etc. and the other teachers treat us like a normal teacher. They do this to make us feel like a real teacher. But I cannot say the same thing for the students." this statement indicates the identity confusion. According to the mentor teachers' opinion, issues caused by the novice teachers include the following: Not becoming the only teacher in class, concern about handing the class over, not being able to acquire teacher identity. M34 "I would never hand over the class to a teacher that does not have application skills." I cannot do it. If I were a parent, I would not want the novice teacher to teach the physics or math lessons " This statement indicates that the problem of handing over the class. 
In the system-based issues, the novice teachers expressed opinions on the following themes: filling forms in cases caused by the system, not being the only teacher in the class, not planning city excursions, out-of-school activities' having no aim, forms' not being suitable for the field, evaluation's not being objective, excessive number of exams, the length of the process, books' and films' not being suitable for the field, length of the evaluation process, having no off-days, assignment outside of one's field, the process's not being at the institution suitable for one's field. About filling forms, NT13 said "We have some form traffic, maybe others told you about this. It would be better to mechanize the forms. We are at school for 6 hours. 3 hours for the plan and preparation, 3 hours course application. I could stay at school for 9 hours and teach the kids. I wish I had spent more time at the institution rather than spending time with the forms. I could replenish my academic knowledge, this could be an advantage for me. Forms are such a burden." NT15 "I do not feel like I am providing a service at this moment. Okay, we teach. However, I do not think that these 3 hours of teaching is effective. I want the students to my own. I teach for 3 hours than the mentor comes in and teaches after 3 hours. After that, I have to continue teaching from where the mentor has left. I want to have a complete class with the students. It is like having only one repairman for a broken washing machine." If a second repairman comes in, everything gets messed up. I believe this is not useful for the students as well." This statement indicates the problem of not being the only teacher in the classroom. NT19, "I don't believe the evaluation process is objective. The mentor that was appointed by the principal gave us our grades. The mentor sees us a little more often. However, the principal usually sees us at the administrative duties. He does not even know our names properly. He does not know how we are as teachers. Thus, his scoring is not too objective. I do not think it is very objective. In addition, the teachers evaluate themselves and the mentors evaluate us. What we do may not make any sense to them. Playing music to entertain the kids etc. My mentor finds it unnecessary. "He complained about the fact that the evaluations were not objective. According to the mentor teachers' opinion, system-based issues include the following: Filling in a large number of forms, the lack of information in the process, wasting time, the evaluation process's being unsettling, evaluation's not being objective, forms not being suitable for the field, the observation forms' not being compatible with the course duration, field-specific operation steps' being not defined, unsupervised system, books' not reflecting the real world, forms' not reflecting the process. M19 "These candidates took the KPSS exam and therefore have been placed. The evaluation is already being carried out at the place they currently work. There is no need to re-evaluate them at another location to which they are appointed. This just makes their job harder. They get nervous. They wonder what they are about to face." This statement refers to the evaluation process being unsettling.

In the context of problems experienced, some of the school administrators said that they did not have any issues, on the other hand they mentioned the following issues: The process not complying with the place appointed, the out-of school activities' not being determined by MEM, carrying out the personnel related tasks of novice teachers, novice teachers' having trouble in adapting to the working rules, the evaluation process's being unsettling. SA5 “Arranging the salaries, personal rights of the novice teachers and arranging the exam payment if they are on duty at an exam, these are to be considered. Our school is already crowded. We have 1200 students and 60 personnel here. We are always dealing with the personal rights, salaries of these people here. If only the provincial directorate for national education helped us out. These extra things get in our way, they are such a burden" with this statement, it is indicated that managing the personal affairs of the novice teachers is a problem.

\section{Suggestions}

Suggestions that the novice teachers and mentor teachers presented were gathered in three main themes; suggestions about mentors, about novice teachers and suggestions for the process.

Suggestions of novice teachers about mentors are the need to be extra vigilant in choosing who is to be a mentor, reduction of burden on mentors, auditing the relationship between novice teachers and mentors, evaluating the mentors and encouraging them. NT35 "When choosing my mentor, I want them to be from the field that I graduated and I want them to take their jobs seriously. I want their knowledge to be tested." Attention to the choice of mentors is stated here. NT20 "I want the mentors to be motivated. This can really help. If they are encouraged, and motivated, we can get motivated too." The importance of encouraging the mentors is given in this statement. According to the mentor teachers' opinions suggestions regarding their own roles include: Personal benefits of mentors should be regulated, mentor authority should be increased, the choice of mentors should be regulated. Regarding the personal rights of the mentor, M4 said "An advantage is needed. For the efforts.", M23 "It could be a work to be honored. Because it was a really serious effort." Suggestions of them regarding their own experience are gathered under the following sub-themes: the chance to be alone in the class should be provided, performance evaluations should be done, and this program should be applied to inexperienced teachers. According to mentor teachers, novice teachers should enter each class.

Novice teachers gave some suggestions regarding the process in the following themes: The forms should be edited, the education length should be shorter, right to choose books and films should be provided, more practice than observation should be ensured, observation forms 
should be kept confidential, the out-of-school activities should be planes by MEM, the scope of social activities should be broadened, regulation should be made on summer holiday issue, the induction to teaching program process should be carried out during the 4th year of the undergraduate program, one exam should be applied with field-specific steps. NT31 "Primary and middle school is suitable for us rather than vocational high schools. Because we are not like culture teachers. Some forms were created for us. Since it does not fit them, I think other forms may be created in the future." This statement is regarding the editing of the forms. NT28 de "Teaching practice in university was only teaching practice. I think that it would be more useful in the last year of the university rather than at the time we started working. I mean, they apply such method as if they are telling us that the education and received at the university was not enough. So, I think what is to be done should be done in the last year of the university." This statement is regarding the fact that the license training should be administered in the 4th year. Suggestions regarding the process given by mentor teachers include: Induction to teaching program must be received at undergraduate level, the number of forms to fill must be reduced, the induction to teaching program's duration must be reduced, field-specific forms should be prepared, mentor's percentage should be increased during the evaluation process, first grade must be seen in the induction to teaching program, exams must be removed, administrative duties in unified village schools' classrooms should also be taught, the book list should include books regarding the real life, interest-based choice in the selection of books should be offered, evaluation forms should be arranged for teacher achievements, grading system must be removed, the novice teachers should be ensured to complete the process at the place they appointed to, plans and forms should be written in a digital environment. M41 said "I wish this process had taken place at the university so that the mentor would not waste time." M10 said "It can be useful to carry this out for a year with the support of Ministry of Education. Combining this system with the system that the ministry applies can be useful. "These statements refer to the fact that this process must be completed in undergraduate years.

The school administrators' suggestions regarding the process are as follows: Paperwork should be reduced, evaluation stress should be eliminated, the universities should support the process, the induction to teaching program should start during the undergraduate years, education inspectors should be removed from the evaluation process, written and oral exam should be included, evaluation with scores should be removed, the training should be carried out at the place appointed, out-of-school activities should be planned for the mentors. SA1 "The universities should support the process. The teacher should be prepared to teach and the education must involve practice. We have problems in this area. If this training program starts in the first year of college and gets expanded, I believe the training will actually work." This statement suggests that it is necessary to start the process during the undergraduate years and expand it.

\section{Discussion, Conclusions and Recommendations}

The findings of this study, in which the induction to teaching program was assessed according to views of novice teachers, mentor teachers and school administrators, were summarized under six main titles. In this section of the research, comparative discussion of the results obtained under these titles is aimed.

When we look at the findings in the context of the introduction to the Novice Teacher process, it is seen that novice teachers, mentors and school administrators talk about an informative meeting and education. All three groups indicated that an informative meeting was held before the start of the process, and it was determined that only principals from school administrators attended this meeting. Novice teachers stated that this meeting was more structured on general issues and that they could not get much information from this meeting about the process and the mentors stated that short training was not enough and they learned some things better in the process. Likewise, in the research conducted by Kozikoğlu and Soyalp [32], it was determined that novice teacher and mentors and school administrators had lack of information about the process. The research conducted by Balkar and Sahin [41] also revealed that the novice teachers expressed their opinion on the fact that the mentor teachers should be trained. Similarly, Soares, Lock and Foster [42] and Ulvik and Sunde [43] pointed out that there is a necessity for formal education to become a mentor. In this context, it would not be wrong to say that it is important that all parties receive effective education before the induction to teaching program is implemented. This was also concluded in the research carried out by Sarikaya, Samanci and Y1lar [31], in which findings were obtained regarding the fact that mentor teachers should carefully selected and trained.

Novice teachers and mentors stated that the process of getting acquainted with the teachers is done through the teachers. School administrators also stated their intention to organize this meeting. It was observed that when the novice teachers entered the classes for the first time, they faced different reactions, but with the help of the mentor teachers, and by defining the statues of the novice teachers in the class, they stated that these reactions changed in positive direction over time. In Alemdağ, Özdemir and Şimşek [44]'s research conducted with the students from computer teaching department taking the teaching practice course, it was revealed that the fact that the mentors not introducing the novice teachers to the students makes the communication process with the students harder for the 
novice teachers, and that the students do not see the novice teacher as a teacher. For this reason, the introduction of new incoming novice teachers or intern teachers to the students in the class and the announcement of their competence will facilitate the communication with the students by strengthening the status of the novice teachers.

Mentors often stated that they are not volunteering to be mentors and that this task is reported to them at the last minute. In the research conducted by Balkar and Sahin [41], it was determined that the novice teachers and especially the teachers to become mentors should be willing to take over the tasks. Similarly, Algozzine, Gretes, Queen, and Cowan-Hathcock [45] found that the mentor's willingness to give time and energy supports the start-up training. In our context, the appointment of mentors without volunteering in the induction to teaching program is a major obstacle to achieving the program's desired success. In the research, school administrators indicated that they selected mentor teachers according to the criteria such as having 10 years of experience, being hard working and successful and being good at teaching. In the summer of 30.12.2015, the General Directorate of Teacher Training and Development decided that the selection of the mentor teachers should be carried out by the school administrators and that the teachers to be selected should have at least ten years of service time, took part in various duties in national or international projects, participated in social and cultural activities , (poetry recitals, school newsletters, school magazines, school trips, sport events, etc.), have communication skills and the ability to represent, are on the frontline in the profession, and are in the same field as the novice teachers. [23]. Grudnoff [46] stated that school principals should take an active role in the selection of novice teachers and in ensuring that they can perform their tasks effectively and correctly. Pogodzinski [47] points out the need for school administrators to choose experienced teachers who can understand novice teachers. In this context, the opinion of school principals can be considered as a positive approach by the Ministry of National Education in the selection of mentor teachers. Daresh [8] stated that problem solving, listening and observation skills are three basic skills that a mentor should have. He stressed that the mentor should be a good teacher, have good classroom management skills, and must have experience in teaching, be open to innovation, be open to learning and individual evaluations, and be able to recognize competencies while evaluating the performances of novice teachers. In the study conducted by Nayır and Kuru Çetin [29] with novice teachers, it was found that the mentors should be senior, equipped with pedagogical information in the context of professional qualities and open to innovations. Especially, it is thought that the selection of the mentor teachers from the senior teachers is important for transferring the existing experiences to novice teachers. As a matter of fact, it was determined that the teachers who have a seniority of 3-6 years in the research carried out by
Yazıcı and Tekerci [48] are inadequate in their teaching skills regarding teaching planning, pre-implementation preparation and vocational guidance. In this context, it can be said that it is a positive criterion for the Ministry of National Education to seek the condition of having a service time of at least 10 years in the mentor selection process.

When novice teachers, mentors and school administrators were asked to compare the new practice with the one the students receive during the undergraduate years, it was found that the novice teacher process was much more comprehensive, intense and long-term, and it was taken more seriously, that the internship schools did not reflect the real school environment, that the undergraduate training was not practice-oriented and that the teaching practice was very structured. In the study carried out by Orhan [49], prospective teachers indicated that students and school personnel had negative attitudes towards prospective teachers in teaching practice and school experience courses, that schools were not selected in a systematic way, that application teachers were inadequate and that excessive workload was given to them. In studies carried out in the field, it was revealed that the mentor teachers who will guide the novice teachers in the teaching practice courses taken during the undergraduate education are lacking in some skills such as planning and giving feedback before implementation, vocational guidance, evaluation of the process $[50,51,48]$. There is also evidence that the practice teachers who will guide the candidates have poor communication with candidates [52, 53,44]. Alemdağ and Özdemir Şimşek [44] found that participants did not relate between the theoretical training in education faculties and the practical experience in practice schools and that in practice teachers could not be a good role model to establish the relationship between theory and practice. Teaching practice is one of the problems determined to be inadequate [54, $55,56,57,58,59,60]$. Studies conducted in the literature generally show that there are some problems experienced in teaching practice courses offered during undergraduate education. In this context, it can be said that the problems identified by the participants within the scope of this research are also confirmed. In the research conducted by Kaya [61] regarding induction to teaching program, novice teachers indicated that they found the opportunity to apply the theoretical knowledge they learned in the university through the applied induction to teaching program and that they were benefiting from mentor teachers especially in class management, lesson planning and execution, different methods and technical use.

When mentors and novice teachers were asked to compare their teaching process with the previous novice teaching process, some indicated that this system is better, while others stated that they think the former system is better. All school administrators say that the induction to teaching program is superior to that of the previous one. 
While both novice and mentor teachers view the former system more useful in the context of getting starting to the teaching profession and doing the teaching immediately, those who see the new system as more beneficial are approaching to gain experience and learn to take measures against problems that may arise. In a lot of studies in the literature, newly assigned teachers seem to be pleased with the training applications they received and that it contributed positively to their vocational developments $[62,63,64,65,66,67,68,69,70,71]$.

The novice and mentor teachers and school administrators do not agree on a common point regarding the place of the training. It was determined that the realization of this training in the appointed place will contribute to the adaptation of the novice teacher to the environment, the students and the school and that it is better to do it in the desired place in terms of adapting to the new process without difficulty and with good examples. Orhan [49] found that prospective teachers assessed the teacher training they received and found it inadequate in cases of different conditions and preparation for working with different groups (village schools, mixed classes, physical conditions, families and students with different cultures and languages). Thus, it can be said that the implementation of the induction to teaching program outside the appointed area may lead to the continuity of similar problems in the teaching process. As a matter of fact, in many studies conducted in the literature, it was determined that the novice teachers have negative opinions regarding the teaching practice outside the assigned province and that there are many adaptation problems in the place assigned in terms of physical environment, cultural structure, physical possibilities of the school $[72,73,32,74,31]$. However, teaching practice in a different province provides support in the context of working with more experienced mentors $[26,73,32]$. In the research conducted by Sarikaya, Samanci and Ylar [31] it was stated that in addition to these findings, being absent in the institution appointed is hampering the education and training activities and paid teachers can be assigned instead of the novice teachers for a period of time. In this context, it can be said that the induction to teaching program supports the professional development of novice teachers, while it is ironic that the teachers who are appointed and permanent staffs are not able to enter a class separately for about six months while paid teachers are employed where there are teacher vacancies.

When the problems in the process are examined, some problems arising from the mentor teacher, the novice teacher and the system are mentioned. In the issues caused by the mentor, the novice teachers gave opinions on the following matters: mentor and novice teacher compatibility, not getting feedback, insufficiency of the mentors, novice teacher comparison, and seeing bad examples. The mentor-based issues include the following: The mentor's having more power, mentorship's becoming the priority according to the mentors. In the research carried out by Ulubey [28] similar to the findings in this study, problems such as the presence of novice teachers in the shadow of mentor teachers and intervention of mentor teachers who teach courses and supervision of mentor teachers were stated. Balkar and Şahin [41] stated that criteria such as teaching at the same level, common knowledge and closeness should be determinative factors in the pairing of mentors and novice teachers. It is also pointed out that the teachers who will be mentors should be individuals who are successful in human relations, have knowledge about the school and the related professional and social resources, sensitive to individual differences, having different instructional strategies and educational program information. LoCasale-Crouch, Davis, Wiens and Pianta [75] stated that the novice teachers who worked at the same level as their mentors received more support. In some studies, it was determined that the mentors were not sufficiently interested in the novice teachers due to the heavy workload [27, 31].

In the issues caused by the novice teacher, various opinions were shared under the themes of confusion of student and teacher identity, inability of feeling of belonging, anxiety and fear, being a burden to the mentor and coping with unwanted behaviors. From the mentors perspective, issues caused by the novice teacher included not becoming the class' teacher, handing the class over, acquiring the teacher identity. Ulubey [28], as a matter of fact, questions such as the fact that the novice teachers were treated as undergraduate students during the process, their tasks were not understood clearly by the mentor teachers and they were assigned to spare lessons. In this context, it is possible to say that student and teacher identity crisis is natural and stems from the process.

Opinions on System-Based Issues concerning the novice teachers were reported under the themes as follows: filling in a large number of forms, forms not being appropriate, excessive amounts of exams, the length of the process, the evaluation not being objective, books and movies not being suitable for the field, out-of-school events being aimless, the length of the evaluation process, being appointed to something not related to your competencies. The mentors stated the following issues: The evaluation process being unsettling, The lack of information in the process, Waste of time, Evaluation not being objective, Forms not being suitable for the field, The observation forms not being compatible with the course duration, Field-specific operation steps not defined, Unsupervised system, Books not reflecting the real world, Forms not reflecting the process. The filled forms being too many became one of the most frequently mentioned problems in other research conducted in the field $[25,28,31,32]$.

Regarding the problems experienced, the school administrators, pointed out various problems such as the lack of compliance with the place where the process was conducted, the out-of-school activities not being 
determined by the MEM, the appointment of the novice teachers, the compliance of the candidates with the working rules, and the evaluation process. In the research carried out by Kozikoğlu and Soyalp [32], problems such as not executing a planned progress and the internal practices not being carried out properly due to the administrators being busy were mentioned.

Suggestions related to the process were gathered in three main themes; suggestions about mentor teachers, about candidate teachers and suggestions for the process. The novice teachers point out the following suggestions: Attention to the choice of mentors, reduction of the mentor's burden, supervision of mentor-candidate communication, evaluation of mentors and encouraging mentors. As for mentors, they pointed out the following suggestions: Personal rights of mentors should be regulated and mentor authority should be increased, criteria regarding the selection of mentors should be determined. In the research conducted by Balkar and Şahin [41], it was seen that the novice teachers reported that the reduction of the course load of the mentor teachers could be perceived as an incentive and that the benefit to be provided from the program could be increased. Similar findings were obtained in other studies conducted in the field [76,77].

Suggestions regarding novice teachers are gathered under the following sub themes: The chance to be alone in the class should be provided, performance evaluations should be done, and this program should be applied to inexperienced teachers. The suggestions of the mentors are as follows: Induction to teaching program must be received at undergraduate level, the number of forms to fill must be reduced, the duration of induction to teaching program must be reduced, field-specific forms should be prepared, mentor's percentage should be increased during the evaluation process, first grade must be seen in the induction to teaching program, exams must be removed, administrative duties in unified village schools' classrooms should also be taught, the book list should include books regarding the real life, interest-based choice in the selection of books should be offered, evaluation forms should be arranged for teacher achievements, grading system must be removed, the novice teachers should be ensured to complete the process at the place they appointed to, plans and forms should be written in a digital environment. Among these suggestions, the suggestion that the induction to teaching program should be received at the undergraduate level is important. Many mentor teachers expressed the dissatisfaction with evaluating colleagues who have similar status to theirs by emphasizing the primary responsibility of the institutions that train teachers in teacher training. During the undergraduate education, it is also a fact that the required teacher qualifications cannot be achieved by taking the lessons within the scope of school experience and teaching practice. The reasons for this were discussed above. It is also important that primary school and village school practices be observed in the process of the induction of teaching program especially for classroom teachers. Similar findings were obtained in the research carried out by Sarıkaya, Samanc1 and Yılar [31]. Especially, the fact that there are a lot of forms filled in the process and the lack of appropriate forms in the field are frequently criticized. [25,28,31,32].

It was determined that the school administrators had suggestions only referring to the process. In these suggestions, the suggestions provided by both the mentors and the novice teachers look similar. The suggestions from the school administrators are gathered under the following sub themes: Paperwork should be reduced, evaluation stress should be eliminated, the universities should support the process, the induction to teaching program should start during the undergraduate years, education inspectors should be removed from the evaluation process, written and oral exam should be included, evaluation with scores should be removed, the training should be carried out at the place appointed, out-of-school activities should be planned for the mentors.

When the findings are examined as a whole, the induction to teaching program is perceived as a positive and necessary practice by both novice and mentor teachers and school administrators. According to the teaching practice course taken during undergraduate education, it was determined that this process was seen as a more serious and detailed process by novice teachers, mentor teachers and school administrators. Compared to the previous induction to teaching program, the school administrators found this process more successful, while it caused disagreements between novice teachers and mentors. It is also stated that the candidate may have different advantages and disadvantages in the place where the training takes place and in the place appointed. This matter led to a disagreement. School administrators required it to be performed at the place appointed. In the context of the problems encountered, the most frequently reported problems was regarding the forms filled. However, problems related to the length and objectivity of the evaluation process are also among the frequently reported problems. Suggestions such as making necessary arrangements in the forms, removing oral examinations or ensuring objectivity are among the frequently mentioned suggestions.

In the context of the findings from the research findings, the following suggestions can be presented for the process:

- $\quad$ Novice teaching process should be planned well; and trainings that explain the process better for candidates, mentors and school administrators could be organized.

- Clear criteria must be determined in the selection of mentor teachers and volunteering may be deemed essential.

- The personal rights of the mentors should be improved. 
- Within the process, the number of forms filled by mentor and novice teachers could be reduced and rearrangements should be made in a way that is appropriate for the teaching profession.

- The evaluation process can be simplified.

- Arrangements should be made for the induction to teaching program to be carried out at the province appointed.

- Induction to teaching program should be rearranged with the universities and shifted to undergraduate education.

For further research, the following suggestions can be presented:

- The «In-Service Training» dimension of Induction to teaching program should be examined.

- The "evaluation" dimension of the Induction to teaching program should be examined in depth.

- The adaptation of teachers who have and have not received the induction to teaching program training into the profession could be further investigated.

\section{REFERENCES}

[1] Yeşilyurt, E. ve Karakuş, M. (2011). Öğretmenlerin adaylık surecinde karşılaştıkları problemler. International Online Journal of Educational Sciences, 3 (1), 261-293. Retrived from http://www.iojes.net//userfiles/Article/IOJES_351.pdf at 05.02 .2016

[2] Korkmaz, İ., Saban, A. ve Akbaşl1, S. (2004). Göreve yeni başlayan sınıf öğretmenlerinin karşılaştıkları güçlükler. Kuram ve Uygulamada Eğitim Yönetimi, 38, 266-277.

[3] Yalçınkaya, M. (2002). Yeni Öğretmen ve Teftiş. Milli Eğitim Dergisi. Say1 153-154.

[4] Crisp, G.; Cruz, I. (2009). Mentoring College Students: A critical review of the literature between 1990 and 2007. Research in Higher Education, 50(6): 525-545

[5] Lyons, W.; Scroggins, D. and Rule,P. B. (1990). The mentor in graduate education. Studies in Higher Education, 15(3): $277-285$

[6] Rhodes, C.; Stokes, M. and Hampton, G.(2004). A practical guide to mentoring, coaching and peer-networking: teacher professional development in schools and colleges. London and New York: RoutledgeFarmer

[7] Jacobi, M. (1991). Mentoring and undergraduate academic success:a literature review. Review of Educational Research, 61(4): 505-532.

[8] Daresh, J.C. (2003). Teachers mentoring teachers: a practical approach to helping new and experinced staff. California: Corwin Pres.

[9] Packard, B.W, (2003): Definition of Mentoring. Mount Holyoke College retrived from
http://ehrweb.aaas.org/sciMentoring/Mentor_Definitions Packard.pdf at 22.07.2017.

[10] Shea, G. F. (1994). Mentoring: helping employees reach their full potential (AMA management briefing). AMACOM.

[11] Yarrow, A., \& Millwater, J. (1997). Evaluating the effectiveness of a professional development course in supervision and mentoring. British Journal of In-service Education, 23(3), 349-361.

[12] Hobson, A. J., Ashby, P., Malderez, A., Tomlinson, P.D. (2009). Mentoring beginning teachers: What we know and what we don't. Teaching and Teacher Education, 25, s. 207-216.

[13] Griffin, K. A. (1999). An exploration of women's mentoring: graduate students' perspective (Unpublished doctoral dissertation). Retrieved from ProQuest Dissertations and Thesis database. (UMI No. 9962263)

[14] Barker, R. T., \& Pitts, M. W. (1997). Graduate students as mentors: an approach for the undergraduate class project. Journal of Management Education, 21(2), 221-231.

[15] Webb, L. D., \& Norton, M. S. (1999). Human resources administration: Personnel issues and needs in education. New Jersey: Prentice-Hall.

[16] Luna, G., \& Cullen, D. L. (1995). Empowering the faculty: Mentoring redirected and renewed. Higher Education Reports, 3, 1-87.

[17] Doyon, D. (2000). Interdepartmental mentoring program for middle managers. Module 1: Basic information, middle managers network and human resources development. Canada: Quebec Region.

[18] Awaya, A., McEwan, H., Heyler, D., Linsky,S., Lum, D., Wakukawa, P. (2003). Mentoring as a journey. Teaching and Teacher Education, 19, s. 45-56.

[19] Randolph, K. A; Johnson, J. L. (2008). School - based mentoring programs: review of the research. Children \& Schools, 30(3): 177 - 185

[20] Eby, L.T. ve Lockwood, A. (2005). Proteges and Mentors' Reaction to Participation in Formal Mentoring Programs: A Qualitative Investigation. Journal of Vocational Behavior, $67,441-458$.

[21] Miller, A. (2002). Mentoring students and young people: a handbook of effective practice. Newyork: Falmer Press.

[22] Milli Eğitim Bakanlığı (MEB). (1995). Milli Eğitim Bakanlığı Aday Memurların Yetiştirilmesine İlişkin Yönetmelik. Tebliğler Dergisi, 58 (2423). 30.01.1995.

[23] MEB (2016a). Milli Eğitim Bakanlığı Öğretmen Atama ve Yer Değiştirme Yönetmeliğì" retrived from http://mevzuat.meb.gov.tr/html/ogratama_2/ogratama_1.ht $\mathrm{ml}$ at 02.01.2016.

[24] MEB (2016b). Aday Öğretmen Eğitimi Programı. Retrived from http://oygm.meb.gov.tr/www/aday-ogretmen-yetistirme-su recine-iliskin-yonerge-ve-yetistirme-programi/icerik/328 at 16.03.2016.

[25] İlyas, İ. E., Coşkun, İ. ve Toklucu, D. (2017). Türkiye'de 
aday öğretmen yetiştirme modeli: İzleme ve değerlendirme. İstanbul: SETA Yayınlar1.

[26] Gül, İ.; Türkmen, F. and Aksel, N. (2017). Aday öğretmen görüşlerine göre aday öğretmen yetiştirme sürecinin değerlendirilmesi. Hitit Üniversitesi Sosyal Bilimler Enstitüsü Dergisi, 10(1): 365 - 388.

[27] Gökulu, A. (2017). Aday öğretmenlerin Türkiye'deki aday öğretmenlik eğitim süreci ile ilgili görüşleri. International Journal of Social Sciences and Education Research, 3(1), 111-123.

[28] Ulubey, Ö. (2017). Aday öğretmen yetiştirme programının değerlendirilmesi. Hacettepe Üniversitesi Ĕ̈itim Fakültesi Dergisi, 201, 1-23, doi: 10.16986/HUJE.2017031014.

[29] Nayır,F.; Kuru Çetin, S. (2017). Opinions of teacher candidates on mentor teacher program (example of Muğla). Journal of Education and Future, 12:137-155

[30] Tunçbilek, M. M. ve Tünay, T. (2017). MEB aday öğretmen yetiştirme süreci uygulamasının ilgili tarafların bakış açısıyla değerlendirilmesi. Elektronik Sosyal Bilimler Dergisi, 16(61), 412-427.

[31] Sarikaya, İ.; Samanc1, Ö.; Yılar, Ö. (2017). Aday öğretmen yetiștirme sürecinin aday ve danıșman sınıf öğretmenlerinin görüşleri kapsamında değerlendirilmesi: bir karma yöntem çalışması. GEFAD / GUJGEF 37(3): 939 - 989

[32] Kozikoğlu, İ. ve Soyalp, H. (2018). Aday öğretmenlerin, danışman öğretmenlerin ve okul yöneticilerinin aday öğretmen yetiştirme programına yönelik görüşlerinin incelenmesi. Hacettepe Üniversitesi Eğitim Fakültesi Dergisi. doi: 10.16986/HUJE.2018037027

[33] Merriam, S. B. (2009). Qualitative research: A guide to design and implementation. San Francisco: Jossey-Bass.

[34] Annells, M. (2006). Triangulation of qualitative approaches: Hermeneutical phenomenology and grounded theory. Journal of Advanced Nursing, 56(1), 55-61.

[35] Yıldırım, A.ve Şimşek, H. (2008). Sosyal bilimlerde nitel araştırma yöntemleri. Ankara: Seçkin Yayıncılık.

[36] Creswell, J. W. (2013). Qualitative inquiry \& resaerch design: Choosing among five approaches (Third edition). New York: Sage.

[37] Fitzpatrick, J. L. , Sanders, J.R. ve Worthen, B.R (2004). Program evaluation. Alternative approaches and practical guidelines (3rd edition). Boston. Allyn and Bacon

[38] Parlett, M. ve Hamilton, D. (1977). Evaluation as illumination: A new approach to the study of innovatory programs. M. Parlett ve G. Dearden (Eds.), in the Introduction to illuminative evaluation: Studies in higher education (p. 9-29). California: Pacific Soundings Press

[39] Ornstein. A. ve Hunkins, F. (2014). Curriculum. Foundation, Principles, and Issues (6th Ed.). England: Pearson International Edition.

[40] Miles, M. B. \& Huberman, A. M. (1994). Qualitative data analysis. California: Sage.

[41] Balkar, B. ; Şahin, S. (2015). Yeni bir öğretmen yetiştirme yaklaşımı olarak göreve başlatma programı. Mersin Üniversitesi Eğitim Fakültesi Dergisi, 11(1): retrived from
http://C:/Users/Pc/Downloads/5000060176-5000171024-1 -PB.pdf at 04. 04. 2016

[42] Soares, A., Lock, R., \& Foster, J. (2008). Induction: the experiences of newly qualified science teachers. Journal of Education for Teaching: International Research and Pedagogy, 34(3), 191-206.

[43] Ulvik, M., \& Sunde, E. (2013). The impact of mentor education: Does mentor education matter? Professional Development in Education, DOI:10.1080/19415257.2012.7 54783

[44] Alemdağ, E.; Özdemir-Şimşek, P. (2017). Pre-service teachers' evaluation of their mentor teachers, school experiences, and theory- practice relationship. International Journal of Progressive Education, 13(2): $165-179$

[45] Algozzine, B., Gretes, J., Queen, A.J., \& Cowan-Hathcock, M. (2007). Beginning teachers' perceptions of their induction program experiences. The Clearing House: A Journal of Educational Strategies, Issues and Ideas, 80(3), 137-143.

[46] Grudnoff, L. (2012). All's well? New Zealand beginning teachers' experience of induction provision in their first six months in school. Professional Development in Education, 38(3), 471-485

[47] Pogodzinski, B. (2012). The socialization of new teachers into teacher unions. LaborStudies Journal. 37(2): 183-202.

[48] Yazıc1, Z; Tekerci, H. (2017). Okul öncesi öğretmen adaylarının mentör ögretmen algısı. Route Educational and Social Science Journal, 4(5): 156 - 166.

[49] Orhan, E. E. (2017). Türkiye'de öğretmen adayları aldıkları öğretmen eğitimi hakkında ne düşünüyor? Nitel bir araştırma. Eğitim ve Bilim, 42 (189):197-216

[50] [50] Akçamete, G., Aslan, B. ve Dinçer, C. (2013). Uygulama öğretmenlerinin mentorluk becerilerinin değerlendirilmesi. Uluslararası Öğretmen Yetiștirme Politikaları ve Sorunları Sempozyumu II, 16-18 May1s 2010 - Hacettepe Üniversitesi, ANKARA / 1141.

[51] Gökçe, E. ve Demirhan, C. (2005), Öğretmen adaylarının ve ilköğretim okullarında görev yapan uygulama öğretmenlerinin öğretmenlik uygulaması etkinliklerine ilişkin görüşleri. Ankara Üniversitesi Eğitim Bilimleri Fakültesi Dergisi, 38(1), 43-71.

[52] Arkün-Kocadere, S., \& Așkar, P. (2013). Okul uygulamaları derslerine ilișkin görüşlerin incelenmesi ve bir uygulama modeli önerisi. Hacettepe Üniversitesi Eğitim Fakültesi Dergisi [Hacettepe University Journal of Education], 28(2), 27-43.

[53] Taşdere, A. (2014). Sınıf öğretmen adaylarının öğretmenlik uygulaması dersine yönelik yaşadıkları sorunlar ve çözüm önerileri. Electronic Turkish Studies, 9(2), 1477-1497.

[54] Aydın, S., Selçuk, A., ve Yeşilyurt, M. (2007). Öğretmen adaylarının "okul deneyimi II" dersine ilişkin görüşleri (Yüzüncü Y1l Üniversitesi Örneği), Yüzüncü Yll Üniversitesi, Eğitim Fakültesi Dergisi, 4 (2), 75-90.

[55] Dursun, Ö. Ö ve Kuzu, A. (2008). Öğretmenlik uygulaması dersinde yaşanan sorunlara yönelik öğretmen adayı ve öğretim elemanı görüşleri. Selçuk Üniversitesi Ahmet 


\section{Keleşoğlu Eğitim Fakültesi Dergisi, 25, 159 -178.}

[56] Becit, G., Kurt, A. A. ve Kabakçı, I. (2009) Bilgisayar öğretmen adaylarının okul uygulama derslerinin yararlarına ilișkin görüşleri, Anadolu Üniversitesi Sosyal Bilimler Dergisi, 9 (1), 169-184.

[57] Şaşmaz-Ören, F., Sevinç, Ö. S. ve Erdoğmuş, E.(2009). Öğretmen adaylarının okul deneyimi derslerine yönelik tutumlarının ve görüşlerinin değerlendirilmesi. Kuram ve Uygulamada Ĕ̆itim Yönetimi, 58, 217-246.

[58] Akpınar, M., Çolak, K. ve Yiğit, E. Ö. (2012). Öğretmenlik uygulaması dersi kapsamında sosyal bilgiler öğretmen adaylarının yeterliklerine yönelik uygulama öğretmenlerinin görüşleri, M.Ü. Atatürk Eğitim Fakültesi Ĕ̈itim Bilimleri Dergisi, 36, 41-67.

[59] Yılmaz, M; Özçakmak, H. (2015). Öğretmen adaylarının öğretmenlik uygulaması dersleriyle ilgili görüşlerinin değerlendirilmesi. Bartın Üniversitesi Eğitim Fakültesi Dergisi, 4(1), 127-136.

[60] Gömleksiz, M. N.; Kan, A. Ü.; Öner, Ü. (2017). Etkili öğretmenlik eğitimi perspektifinde öğretmenlik uygulaması dersine eleştirel bir yaklaşım: nitel bir inceleme. Tarih Okulu Dergisi, 10(XXXII), 927-954

[61] Kaya, S. (2016). Mentor and candidate teachers' views about the recent teacher induction program. 4th International Conference on Curriculum and Instruction, Antalya-Türkiye.

[62] Huling-Austin, L. (1992). Research on learning to teach: Implications for teacher induction and mentoring programs. Journal of Teacher Education, 43(3), 173-180.

[63] Holloway, J. H. (2001). Research link: The benefits of mentoring. Educational Leadership, 58(8), 85-86.

[64] Thompson, M., Paek, P., Goe, L., \& Ponte, E. (2005, April). The impact of new teacher induction on teacher practices and student learning. In Annual Meeting of the American Educational Research Association. Montreal, Canada: Educational Testing Service.

[65] Raffel, J. A., \& Holbert, R. R. (2006). Preliminary evaluation of the delaware new teacher mentoring/1nduction program. Institute for Public Administration, College of Human Services, Education \& Public Policy, University of Delaware.

[66] Lindgren, U. (2007). Experiences of beginning teachers a school-based mentoring program in Sweden. Educational Studies, 31(3), 251-163.

[67] Kane, R. G. (2008). Evaluation of the new teacher induction program (NTIP) year one results executive summary. University of Ottawa.
[68] Waters, L. L. (2009). An evaluation of novice teachers' perceptions of the mentoring experience in Knox Country schools (Unpublished doctoral dissertation). Retrieved from ProQuest Dissertations and Thesis database. (UMI No. 3361657)

[69] Ingersoll, R., \& Strong, M. (2011). The impact of induction and mentoring programs for beginning teachers: A critical review of the research. Review of Education Research, 81(2), 201-233.

[70] Mastapha, Y. (2011). The components of new teacher support system: Exploring the experiences of novice teachers and mentors who participate in a school based mentoring reform (Unpublished doctoral dissertation). Retrieved from ProQuest Dissertations and Thesis database. (UMI No. 3489826)

[71] Mingo, A. L. W. (2012). Evaluating the impact of the beginning teacher induction program on the retention rate of beginning teachers. Gardner-Webb University.

[72] Altıntaş, S. ve Görgen, İ. (2016). Aday Öğretmen Yetiștirme Sistemi Üzerine Aday Öğretmenlerin Değerlendirmeleri. Proposal at 4th International Conference on Curriculum and Instruction, 27-30 Ekim 2016, Belek/Antalya-Türkiye.

[73] K1lıç, D., Babayiğit, Ö. ve Erkuş, B. (2016). Aday Öğretmenlerin Adaylık Eğitimine İlișkin Görüşleri. Ekev Akademi Dergisi, 20(68), 81-91.

[74] Kozikoğlu, İ. (2016). Öğretimin İlk Y1lı: Mesleğin İlk Yılındaki Öğretmenlerin Karşılaştıkları Güçlükler, Hizmet Öncesi Eğitim Yeterlikleri ve Mesleğe Adanmışlıkları. Unpublished doctoral dissertation, Yüzüncü Y1l Üniversitesi, Eğitim Bilimleri Enstitüsü, Van.

[75] LoCasale-Crouch, J., Davis, E., Wiens, P., \& Pianta, R. (2012). The role of the mentor in supporting new teachers: Associations with self-efficacy, reflection, and quality. Mentoring \& Tutoring: Partnership in Learning, 20(3), 303-323

[76] Helms-Lorenz, M., Slof, B., Vermue, C.E., \& Canrinus, E.T. (2012). Beginning teachers' self-efficacy and stress and the supposed effects of induction arrangements. Educational Studies, 38(2), 189-207.

[77] van Velzen, C., van der Klink, M., Swennen, A., \& Yaffe, E. (2010). The induction and needs of beginning teacher educators. Professional Development in Education, 36(1-2), 61-75.

[78] Berger, P. L. ve Luckmann, T. (2008). Gerçekliğin sosyal inşasl: Bir bilgi sosyolojisi incelemesi. (The social construction of reality) İstanbul:Paradigma. 